\title{
TWO NEW SPECIES OF FERNS FROM SURINAME*
}

\author{
K. U. KRAMER \\ Instituut voor Systematische Plantkunde, Utrecht
}

\section{Adiantum tripteris Kramer, spec. nova (fig. 1)}

Rhizoma breviter repens, squamis integris; petioli et rhachides glabrae. Lamina tripartita, pars medialis bipinnata, laterales semipedatae vel subsemipedatae; pinnulae tenuiter herbaceae, dimidiatae, circumscriptione $\frac{1}{4}$-elliptica, obtusae; lobi sorales hippocrepiformes, in sinibus profundis dispositi.

Rhizome short-creeping to ascending, ca. $5 \mathrm{~mm}$ in diameter; scales medium brown, yellowish brown in transmittent light, very narrowly triangular, $2 \mathrm{~mm}$ long, $0.3 \mathrm{~mm}$ wide, entire. Leaves close; petiole atropurpureous or dark reddish brown, smooth, lustrous, ca. $15-40 \mathrm{~cm}$ long, about as long as to slightly longer than the lamina, flattened in drying but apparently adaxially shallowly channelled and somewhat pale-margined. Lamina ca. $15-30 \mathrm{~cm}$ long, tripartite, the middle part bipinnate, the lateral ones semipedate or subsemipedate; colour medium to dark green when dry but described as pale glaucous by the collectors; texture thinly herbaceous. Axes atropurpureous to dark reddish brown, without indument, adaxially flattened and with slightly paler margins. Central part of lamina ca. 20-27 cm long, at the base with one or a few pairs of petiolulate secondary pinnae (except in smaller, sterile, apparently not full-grown plants where it is simply pinnate), these ca. $4-8 \mathrm{~cm}$ long and with 5-10 pinnules to a side and a terminal one; upper part with simple, comparatively large (primary) pinnules. Lateral parts of lamina two, alternate, inserted $1-3 \mathrm{~cm}$ from each other and from the basal secondary pinnae of the central part, rather strongly ascending, each branching semipedately as in Adiantum pedatum L., but the basal acroscopic secondary division of the lowest point of division not always simple as in that species, but in larger leaves pinnate, with 2-8 pinnules; apart from this the lateral parts 3 or 4 times pseudodichotomously furcate; larger divisions with ca. 16-20 non-contiguous pinnules to a side. Larger (ultimate) pinnules 13 by 7 to 22 by $11 \mathrm{~mm}$, twice as long as wide, dimidiate, $\frac{1}{4}$-elliptic, with straight or slightly concave lower and outward increasingly convex upper/outer margin, the basal ones with a petiolule of up to $3 \mathrm{~mm}$, the upper ones subsessile; the sclerotic tissue of the petiolules extending into the pinnules, these non-articulate. Upper pinnules little reduced; terminal pinnule flabellate, asymmetric, \pm lobed. Margin of sterile (parts of) pinnules with a few narrow acute incisions up to $1 \mathrm{~mm}$ deep, otherwise faintly sinuate; veins evident, free, 2 or 3 times forked, ca. $\frac{1}{2} \mathrm{~mm}$ apart, ending between the faint bulges of the

* Dedicated to Professor Dr. C. E. B. Bremekamp. 


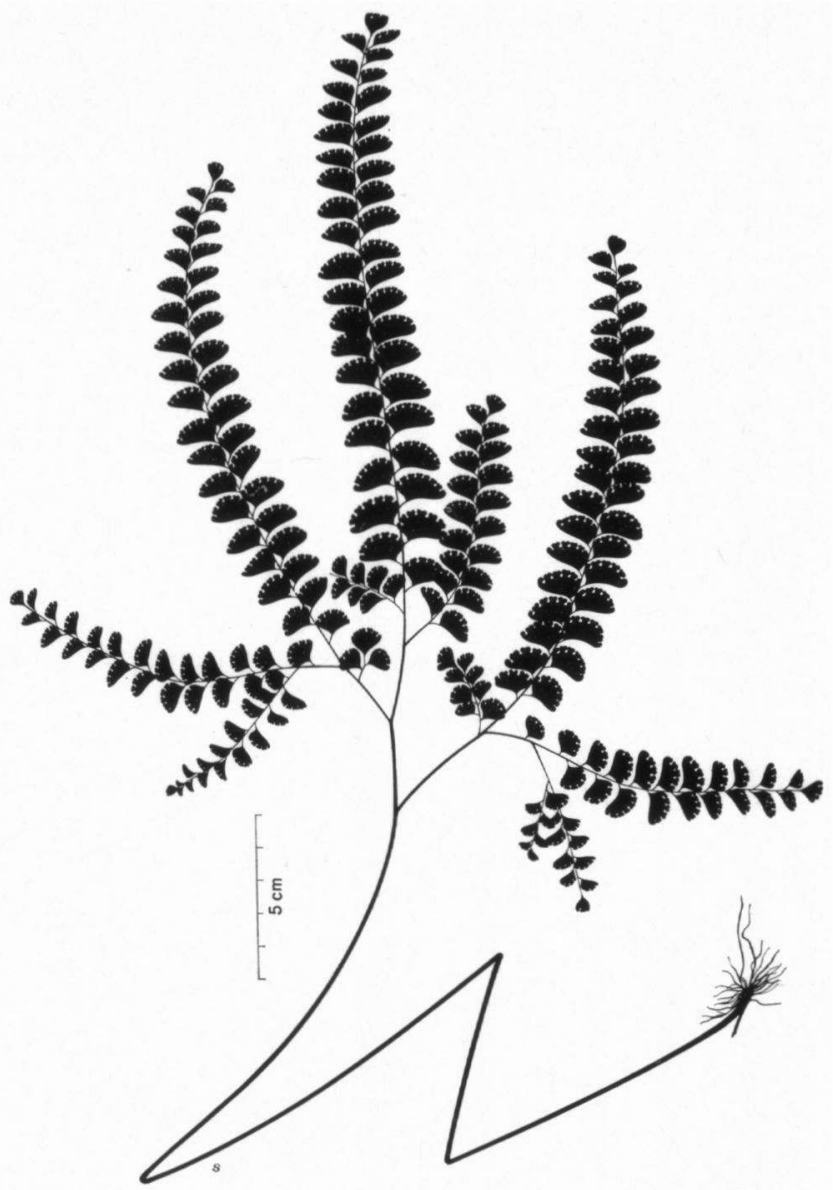

Fig. 1. Adiantum tripteris Kramer.

margin. Fertile pinnules with 3 to 5 soral lobes on the upper/outer margin, these usually alternating with incisions up to $1 \mathrm{~mm}$ deep; each lobe in a deep sinus with \pm touching lips; soral lobe hippocrepiform, $1-1 \frac{1}{2}$ by $1 \mathrm{~mm}$, receiving two veins and containing 3 to 5 veinlets, brownish and somewhat bulging at maturity. Sporangia crowded on the veinlets, with ca. 18 bow-cells; spores medium brown, ca. $50 \mu$ across as seen from the inner side, minutely verruculose.

Type and only known collection: Schulz and Elburg 10187, Suriname, Wilhelmina Mts., southern side of Julianatop, elev. $1000 \mathrm{~m}$. Terrestrial, on base of moss-covered granitic rock, rooting in some mineral soil in crack, in the shade of thin wood, 25 VII $1963(U)$.

The closest relatives of this species are apparently Adiantum curvatum Kaulf., $A$. brasiliense Raddi, and $A$. patens Willd. The two first-named species have a 
similar leaf architecture but are of firmer texture, with more pointed lateral and terminal pinnules, have more wide-creeping rhizomes, and, especially, straight or only faintly concave soral lobes not located in deep sinus. From A. patens the new species differs in the not truly pedate leaf pattern, the entirely glabrous axes, thinner pinnules, and entire rhizome scales.

The pedate leaf pattern in ferns was discussed by WAGNER (1952), with A. pedatum $\mathrm{L}$. as an example, probably another relative of $A$. tripteris.

\section{Thelypteris holodictya Kramer, spec. nova. (fig. 2)}

Rhizoma breviter repens; squamae pilis simplicibus acicularibus obsitae. Lamina herbacea, simpliciter pinnata, pinnis 2-4-jugis cum impari, saltem ad petioli rhachidisque sulcum et ad venas maiores pilis simplicibus acicularibus tenuiter vestitum, inter venas glabra; venatio usque ad marginem menisciiformis, venulis excurrentibus plerumque liberis; sori plerumque geminati juxta venulam excurrentem; indusium hippocrepiforme, levissime ciliolatum.

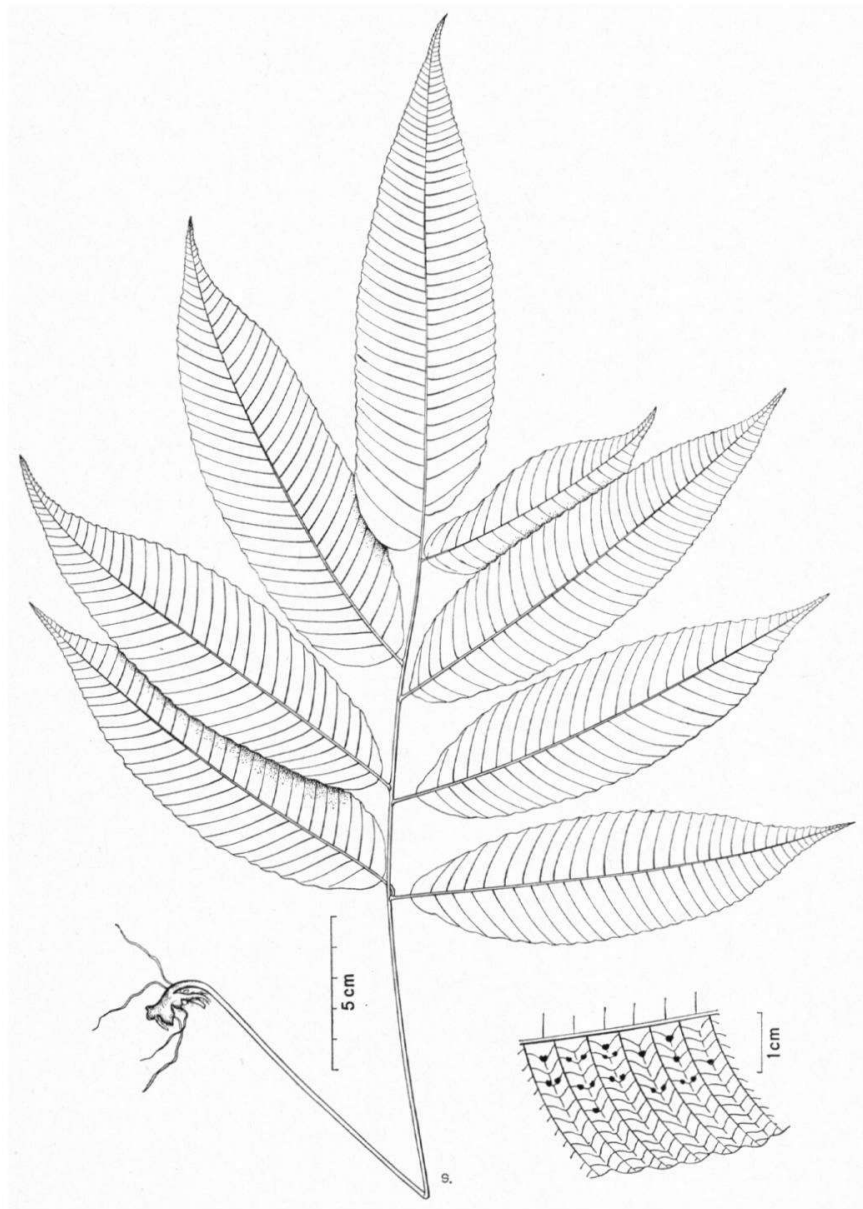

Fig. 2. Thelypteris holodictya Kramer. 
Rhizome short-creeping, 6-7 $\mathrm{mm}$ in diameter; scales castaneous, lustrous, very narrowly lanceolate, ca. $5 \mathrm{~mm}$ long and $0.6 \mathrm{~mm}$ wide, rather densely ciliate with unicellular acicular bristles, the surface thinly hairy with similar bristles, these $1 / 10 \mathrm{~mm}$ long. Leaves distichous, crowded at the rhizome apex; petioles ca. $25 \mathrm{~cm}$ long, ca. $1 \mathrm{~mm}$ in diameter at the base of the lamina, stramineous, glabrescent, deciduously scaly at the extreme base, with two vascular bundles. Lamina herbaceous, olivaceous brown when dry, ca. 20-30 cm long, as wide or a little narrower, simply pinnate, with 2-4 pinnae to a side and a conform terminal one; rachis stramineous, short-puberulent, glabrescent, except in the adaxial furrow; aerophores none. Pinnae spreading or especially the upper ones ascending, subopposite or the upper ones alternate, 2 to $4 \mathrm{~cm}$ apart, with a petiolule of a few $\mathrm{mm}$, the uppermost ones subsessile, broadly lanceolate, 9-16 $\mathrm{cm}$ long, $3-4 \frac{1}{2} \mathrm{~cm}$ wide, the terminal to $6 \mathrm{~cm}$ wide, rounded or the basal ones usually somewhat cuneate at the base, there often asymmetric, either the posterior or the anterior side wider; apex of pinnae acuminate, with an acute tip. Upper pinnae scarcely reduced or one more strongly reduced one very close to the terminal pinna. Margin of pinnae slightly thickened, shallowly sinuate, the basal $\frac{1}{4}$ subentire (except in the terminal pinna which may be superficially lobed at the base). Costa stramineous or pale reddish brown, percurrent, adaxially sulcate, abaxially elevated, rounded. Secondary veins 25-30 to a side, abaxially slightly raised, emerging under a very open angle, slightly curved-ascending, 4-6 $\mathrm{mm}$ apart, often forked at the extreme end, the branches reaching the margin. Tertiary veins ca. 9-jugate, straight or slightly ascending, the basal posterior one sometimes emerging from the costa, all (or all but the very uppermost ones) anastomosing in pairs and forming a meniscioid vein-pattern, the areoles 2-3 $\mathrm{mm}$ high, the excurrent veinlet with a clavate end, falling short of the next arch or occasionally, in the outermost meshes, reaching it. Petiole, rachis, petiolules at least in the adaxial furrow, costa abaxially and in the adaxial furrow, and secondary veins bearing a thin, very short indument of white hairs $\frac{1}{10}-\frac{1}{20}$ $\mathrm{mm}$ long, glabrescent with age, especially the secondary veins, the petiole base more persistently hairy, the leaf margin thinly ciliate with hairs to $\frac{1}{5} \mathrm{~mm}$ long. Sori on the transverse arches, usually two near the middle, $2 \mathrm{~mm}$ apart to contiguous, the anterior one often closer to the excurrent vein, or one of the sori wanting; indusium dark, roundish, deeply hippocrepiform, almost peltate, $\frac{1}{2}-$ $\frac{3}{4}$ in diam., exceedingly sparingly ciliate but the hairs possibly abraded, the surface perhaps originally also sparingly pilose. No well-developed sporangia seen.

Type and only known collection: B.W. (Gonggrijp and Stahel) 609, Suriname, Brownsberg, Brownscreek, at the first waterfall, elev. ca. $200 \mathrm{~m}, 11$ VI 1915 (U). The closest relative of this species seems to be the Panamese Thelypteris clypeata (Maxon \& Morton) Kramer ${ }^{1}$ ), which unfortunately I only know by its description. Judging from the extensive original description, there are many points of similarity in leaf pattern, indument, size, and venation. Th. holodictya has

1 Thelypteris clypeata (Maxon \& Morton) Kramer, comb. nov., basionym: Dryopteris clypeata Maxon \& Morton in MorTon, Bull. Torr. Bot. Cl. 66: 52, 1939. 
smaller, more numerous pinnae with fewer secondary veins and especially a non-peltate indusium. In the paper in which Dryopteris clypeata was described the authors compared it with Cyclodium meniscioides (Willd.) Kuntze, and other species referable to Stigmatopteris, at that time regarded as a subgenus of Dryopteris sensu lato; but according to current ideas with regard to the ferns formerly referred to Dryopteris it is evident that $T$. clypeata and Th. holodictya both belong in Thelypteris subgenus Cyclosorus (Link) Morton as discussed by Morton (1963). A more difficult problem is in what section they belong. The venation is entirely meniscioid, but the round, indusiate sori are unlike those of the species of section Meniscium. A somewhat similar species with round sori is Thelypteris ghiesbreghtii (Hooker) Morton, usually referred to section Goniopteris. It lacks branched hairs, a character that is usually regarded as crucial for that section, but this is again contested by MorTon (l.c.). The material of $T h$. ghiesbreghtii I saw has exindusiate sori. There is also some resemblance to the Asiatic group Abacopteris which includes some species rather similar to $T h$. holodictya, e.g., Abacopteris multilineata (Wall. ex Hooker) Ching. Abacopteris was not dealt with in MORTON's paper (l.c.); HolTTUM (1954) treated it as a genus but stated that it would probably better be included in Cyclosorus, and IWATSUKI (1964) made it a subgenus of Thelypteris, having previously (1959) given it generic rank. Both CHRISTENSEN (1912, p. 268) and HoltTUM (l.c.) stated that the affinity of Abacopteris is with Cyclosorus rather than with Meniscium, as formerly claimed. This may be true, but so far I have not come across any specified arguments for this assertion. At any rate it is clear that the taxonomic position of $T$. holodictya within subgenus $C y c l o s o r u s$ cannot be established before the delimitation of the above-named groups has been carefully worked out.

\section{REFERENCES}

Christensen, C. (1912): A monograph of the genus Dryopteris. I. The tropical American pinnatifid-bipinnatifid species. Kgl. Danske Vidensk. Selsk. Skr., 7.R., Naturv. Math. Afd. X.2: 55-282.

Holttum, R. E. (1954): A revised flora of Malaya. II. Ferns of Malaya. Govt. Printing Office, Singapore.

Iwatsuki, K. (1959): Taxonomic studies of Pteridophyta III. A revision of the species of Abacopteris in the Ryukyus and Taiwan. Acta Phytotax. Geobot. 18: 1-13.

- (1964): Taxonomic studies of Pteridophyta VIII. Classification of the genus Thelypteris s. lat. Acta Phytotax. Geobot. 21 : 35-42.

Morton, C. V. (1963): The classification of Thelypteris. Am. Fern J. 53: 149-154.

W AGNER, W. H., Jr. (1952): Types of foliar dichotomy in living ferns. Am. J. Bot. 39: 578-592. 